\title{
Thermal inhibition and recovery of the maximum quantum yield of photosystem II and the maximum electron transport rate in zooxanthellae of a reef-building coral
}

\author{
Ranjeet Bhagooli ${ }^{* 1,2,3}$ and Michio Hidaka ${ }^{1}$
}

\author{
${ }^{1}$ Department of Chemistry, Biology and Marine Science, University of the \\ Ryukyus, Nishihara, Okinawa 903-0213, Japan. \\ ${ }^{2}$ Institute of Water and Environmental Resource Management, Department of \\ Environmental Sciences, University of Technology, Sydney, Westbourne St, \\ GORE HILL 2065 NSW, Australia \\ ${ }^{3}$ The Biodiversity and Environment Institute, Reduit, Mauritius
}

\begin{abstract}
To examine whether damage to zooxanthellar photosystem II (PSII) is the primary step of thermally induced coral bleaching, we first assessed the relationship between the maximum quantum yield of PSII $\left(F_{v} / F_{m}\right)$ or active PSII centers $\left(F_{v} / F_{o}\right)$ and maximum electron transport rate $\left(E T R_{\max }\right)$, which represent the PSII activity and electron flow beyond the PSII, respectively, in the symbiotic algae of the coral Pachyseris rugosa. Next, the photo-physiological responses of the symbionts to stress treatments of $1 \mathrm{~h}$ high temperature $\left(33.5^{\circ} \mathrm{C}\right)$ and/or high light $\left(1030 \mu \mathrm{mol}\right.$ quanta $\left.\mathrm{m}^{-2} \mathrm{~s}^{-1}\right)$ stress and 6 $\mathrm{h}$ recovery were investigated. The $1 \mathrm{~h}$ high temperature treatment in darkness produced a significant, but reversible $\left(6 \mathrm{~h}\right.$ recovery) decline in $E T R_{\max }$ without any change in $F_{v} / F_{m}$. The $1 \mathrm{~h}$ high light treatment reduced $F_{v} / F_{m}$, but not $E T R_{\max }$. High temperature in combination with high light resulted in a more pronounced reduction in $F_{v} / F_{m}$, along with a significant decline in $E T R_{\max }$. Neither $F_{v} / F_{m}$ nor $E T R_{\max }$ recovered fully within $6 \mathrm{~h}$. Reversible increases in non-photochemical quenching (NPQ), energy dissipation in PSII, were also recorded. Chloramphenicol (CAP), an inhibitor of synthesis of D1 protein of PSII reaction center, revealed that a minimum of $\sim 60 \%$ of the $F_{v} / F_{m}$ or $\sim 30 \%$ of active PSII centers $\left(F_{v} / F_{o}\right)$ is required to maintain $E T R_{\max }$ in the in hospite symbionts. These results suggest that the primary step of heat-induced damage in the symbiont's photosynthetic apparatus involves a component beyond the PSII, probably at the level of the dark reaction as indicated by reduced $E T R_{\max }$ and the PSII damage is secondary.
\end{abstract}

Key words: coral, bleaching, PAM fluorometry, thermal stress, PSII

${ }^{*}$ Corresponding author. Fax: +81-98-895-8576; E-mail: rbhagooli@gmail.com

\section{INTRODUCTION}

Coral bleaching, characterized by loss of endosymbiotic dinoflagellates (= zooxanthellae) and/or their pigments, has been linked to global climate change. Elevated seawater temperatures and solar radiation have received considerable attention as plausible large-scale causes (Glynn 1993; Hoegh-Guldberg 1999; Wilkinson 2000). Bleaching related to high irradiation is widespread in corals on shallow intertidal reef flats throughout the tropics, where levels of light above saturation are potentially damaging to the photosynthetic machinery of the zooxanthellae (Brown et al. 1999; Hoegh-Guldberg and Jones 1999; Lesser and Gorbunov 2001). Exposure to elevated temperatures can also reduce the photosynthetic rate of zooxanthellae (HoeghGuldberg and Smith 1989; Warner et al. 1996) and might predispose their photosynthetic apparatus to further damage by excess light (Fitt and Warner 1995; Lesser 1996; Jones et al. 2000; Bhagooli and Hidaka 2004). In most cases, wherever coral reef bleaching has been reported, 
it occurred during the summer season when conditions favor localized heating in combination with higher intensities of solar irradiance than usual (Hoegh-Guldberg 1999). The key to understanding the underlying photo-physiological mechanism of coral bleaching lies in the explanation of how elevated temperature enhances the effect of incident irradiance. In order to investigate such a phenomenon, it is necessary to identify (1) which component of the photosynthetic machinery fails when zooxanthellae are $\mathrm{ex}^{-}$ posed to thermal stress, (2) what is the definitive sequence of events leading to the destabilization of their photosynthetic function, and (3) the dynamics of recovery of the photochemical efficiency in corals following heat damage.

Several studies on the mechanisms of coral bleaching, from the zooxanthellae photo-physiological perspective, have been undertaken over the last decade. Using the oxygen-evolution method with/without DCMU (3-(3,4-dichlorophenyl)-1, 1dimethylurea, a herbicide inhibiting photosynthesis) fluorescence, evidence for damage to cultured zooxanthellar photosynthesis at temperatures above $30^{\circ} \mathrm{C}$ has been reported (IglesiasPrieto et al. 1992). Damage to both photosystem II (PSII) (Jones et al. 1998; Warner et al. 1999; Bhagooli and Hidaka 2002, 2003, 2004) and the activity of the primary carboxylating enzyme, Rubisco, resulting in a decrease in productivity of thermally stressed cultured zooxanthellae have been described (Lesser 1996). Use of chlorophyll fluorescence fluorometry has led to the suggestion of a photo-physiological mechanism for coral bleaching (Jones et al. 1998; Bhagooli and Hidaka 2004) emphasizing that carboxylation within the Calvin cycle is the first site of heat damage, as has been observed in higher plants under thermal stress (Feller et al. 1998; Crafts-Brandner and Law 2000). On the other hand, PSII as the heat-stress target, particularly damage to the D1 protein of the PSII reaction center has been reported to occur in in hospite zooxanthellae at elevated temperatures and is thus regarded as the determinant of coral bleaching (Warner et al. 1999). Consequently, the primary site of heat damage and its secondary effect on the photosynthetic machinery by light are still subject to debate.

Recent investigations have focused on the recovery of maximum quantum yield and/or maximum electron transport rate using chlorophyll fluorescence techniques in in hospite zooxanthellae of several coral species, with special attention given to explaining bleaching susceptibilities
(Takahashi et al. 2004; Yakovleva and Hidaka 2004). Takahashi et al. (2004) have suggested the repair machinery of PSII as the primary target of heat stress among four scleractinian corals. In contrast, Yakovleva and Hidaka (2004) have put forward the 'differential recovery hyp othesis' based on differential recovery of the PSII and the electron transport rate (ETR) in one bleaching-susceptible and one bleaching-resistant coral. This controversy can be resolved more appropriately by understanding the relationship between PSII and the maximum electron transport rate $\left(E T R_{\max }\right)$. We further need to comprehend how damage to and recovery of both PSII and $E T R_{\max }$ affect a given scleractinian coral following exposure to elevated temperature.

Simultaneous comparison of the dynamic changes in chlorophyll fluorescence parameters such as the maximum quantum yield of PSII $\left(F_{v} / F_{m}\right)$ and ETR (electron flow beyond PSII) allows us to conduct a rapid assessment of the effects of temperature and/or light stresses on the PSII photochemical efficiency and electron flow beyond the PSII in in hospite zooxanthellae. Therefore, the present study attempts to clarify the primary step of photo-physiological damage and associated phenomena under heat and light stresses in the zooxanthellae of the scleractinian coral Pachyseris rugosa using pulse-amplitude modulated (PAM) fluorometry. Recovery of thermally stressed corals was measured to assess how reversible effects were. Non-photochemical quenching (NPQ), a measure of dissipation of excitation energy in PSII as heat mainly via the xanthophyll cycle, was also monitored. Furthermore, the relationships between the maximum quantum yield of PSII or active PSII centers and ETR $R_{\max }$ were evaluated in the presence of chloramphenicol (CAP), a chloroplast-encoded protein synthesis inhibitor.

\section{MATERIALS AND METHODS}

\section{Collection and maintenance of specimens}

Four colonies of the scleractinian coral, Pachyseris rugosa, were collected from a depth of 1-2 $\mathrm{m}$ at Sesoko Island, Okinawa, Japan. Colonies were maintained in shaded, aerated and flow-through outdoor tanks for $24 \mathrm{~h}\left(<400 \mu \mathrm{mol}\right.$ quanta $\left.\mathrm{m}^{-2} \mathrm{~s}^{-1}\right)$ before they were fragmented $\left(\sim 1 \times 1.5 \mathrm{~cm}^{2}\right)$. Fragments were allowed to recover for 9-12 days. The temperature in the tanks was 21.4 $\pm 0.73^{\circ} \mathrm{C}$ (range, $20.5-23.3^{\circ} \mathrm{C}$, Tidbit temperature data logger). 


\section{Experimental protocols}

Before treatments, coral fragments were darkadapted, and $F_{v} / F_{m}$ and rapid light curves (RLC) were measured. Fragments were then exposed to either 25 or $33.5^{\circ} \mathrm{C}$ in darkness or high light (1030 $\mu \mathrm{mol}$ quanta $\mathrm{m}^{-2} \mathrm{~s}^{-1}$ ) for $1 \mathrm{~h}$, followed by a $6 \mathrm{~h}$ recovery period in $\operatorname{dim}$ light $(\sim 3 \mu \mathrm{mol}$ quanta $\left.\mathrm{m}^{-2} \mathrm{~s}^{-1}\right)$ in an indoor flow-though seawater tank. Photosynthetic parameters were again monitored after treatment and recovery. A $1 \mathrm{~h}$ treatment period was chosen to detect early changes in photo-physiological characteristics, using the chlorophyll fluorescence parameters, which usually precede the bleaching process via decrease in chlorophyll content or loss of zooxanthellae from the coral. A $1 \mathrm{~h}$ treatment to high temperature and/or light might not be mimicking the actual field situation, but it will definitely provide valuable insights into the early alteration in the photosynthetic parameters when corals are exposed to elevated temperatures. Previous research showed that recovery periods of 6 and $8 \mathrm{~h}$ are sufficient to have a significant (Porites cylindrica) and complete (Stylophora pistillata) restoration of dark-adapted $F_{v} / F_{m}$, respectively (Hoegh-Guldberg and Jones 1999).

The coral fragments were placed in $300 \mathrm{ml}$ containers filled with $70 \mathrm{ml}$ FSW. These containers were placed in water baths with temperature control units (RACOMACE, Model HT10D and EYELA, Thermister Tempet T-80). The light source was provided by optical fibers from either Coldspot or Nikon light systems and light intensities were measured by a LICOR lightmeter (Model, LI-250). One coral fragment out of four fragments per colony was used for each treatment $\left(25^{\circ} \mathrm{C}\right.$ in darkness, $25^{\circ} \mathrm{C}$ under high light, $33.5^{\circ} \mathrm{C}$ in darkness and $33.5^{\circ} \mathrm{C}$ under high light). To provide four replicates, the experiment was carried out four times using healthylooking coral fragments from the four respective colonies, except for $33.5^{\circ} \mathrm{C}$ treatment in darkness, where $\mathrm{n}=3$.

To examine the relationship between the maximum quantum yield of PSII $\left(F_{v} / F_{m}\right)$ and the maximum electron transport rate $\left(E T R_{\text {max }}\right)$, chloramphenicol (CAP), an inhibitor of chloroplastencoded protein synthesis was employed. CAP prevents the synthesis of PSII reaction center D1 proteins (Schnettger et al. 1994). When the number of functional PSII centers decreases beyond a certain level, then the $E T R_{\max }$ will start to decrease too. Thus, we can estimate the level of maximum quantum yield of PSII $\left(F_{v} / F_{m}\right)$ or the number of functional PSII centers $\left(F_{v} / F_{o}\right)$ required to maintain the maximum electron transport rate (Behrenfeld et al. 1998; Crofts et al. 1993). Coral fragments were incubated in 70 $\mathrm{ml}$ of either FSW (controls) or $400 \mu \mathrm{g} \mathrm{ml}{ }^{-1}$ CAP (prepared with FSW) and exposed to $250 \mu \mathrm{mol}$ quanta $\mathrm{m}^{-2} \mathrm{~s}^{-1}$ at $25^{\circ} \mathrm{C}$ for $15,45,60,120,180$, 240, 360 and $480 \mathrm{~min}$. Since CAP at a concentration of $200 \mu \mathrm{g} \mathrm{ml}^{-1}$ for $120 \mathrm{~min}$ had no significant effect on $F_{v} / F_{m}$ of cultured symbiotic algae (Warner et al. 1999), we employed higher concentration in order to obtain significant effect of CAP on $F_{v} / F_{m}$ within one-hour treatments. Corals were pre-incubated in CAP for 15 min prior to exposure to light treatment. Measurements of chlorophyll fluorescence were done at $25^{\circ} \mathrm{C}$ in FSW before and after exposure to light treatment at various time intervals. Both $F_{v} / F_{m}$ and RLC were recorded in FSW prior to pre-incubation in CAP but for CAP-treated samples measurements were done in CAP solution after treatment.

\section{Chlorophyll a fluorescence measurements}

In this study, chlorophyll fluorescence was determined using a pulse-amplitude modulated (PAM) fluorometer (MINI-PAM: Walz, Germany), and the following parameters were measured: minimum fluorescence $\left(F_{o}\right)$, maximum fluorescence $\left(F_{m}\right)$, maximum quantum yield $\left(F_{v} / F_{m}\right)$, electron transport rate $(E T R)$ and non-photochemical quenching (NPQ). After dark-adaptation for 20 min., $F_{v} / F_{m}$ was determined prior to and after 1 $\mathrm{h}$ treatments to high temperature and/or high light stresses and after $6 \mathrm{~h}$ recovery. The ratio of variable to maximal fluorescence in a darkened sample (dark-adapted $F_{v} / F_{m}$ ) is correlated to the maximum quantum yield of PSII (Genty et al. 1989). Under normal conditions, a linear relationship between the fraction of PSII reaction centers and $F_{v} / F_{o}$ has been reported (Crofts et al. 1993), and $F_{v} / F_{o}$ can be approximately estimated from its hyperbolic relation with $F_{v} / F_{m}$ as $F_{v} / F_{m} /\left(1-F_{v} / F_{m}\right)$.

Rapid light curves for ETR and NPQ were measured after a five minutes light adaptation at $85 \mu \mathrm{mol}$ quanta $\mathrm{m}^{-2} \mathrm{~s}^{-1}$ followed by a $30 \mathrm{~s}$ dark period. The internal light source provided light intensities ranging from $0-460 \mu \mathrm{mol}$ quanta $\mathrm{m}^{-2} \mathrm{~s}^{-1}$ at intervals of $20 \mathrm{~s}$ to produce the rapid light curves (RLCs). The range $0-460 \mu \mathrm{mol}$ quanta $\mathrm{m}^{-2} \mathrm{~s}^{-1}$ was used to prevent any damage due to high light to the photosynthetic apparatus and thus allowed reliable repeated measurements to be possible. Maximum electron transport rate $\left(E T R_{\max }\right)$ entails both the assimilatory and non-assimilatory electron flow, which 
thus can be taken as electron flow beyond PSII. Linear relationships between gross photosynthesis rate measured by $\mathrm{O}_{2}$ evolution and ETR were found under moderate irradiances (Yakovleva and Hidaka 2004; Wu et al. 2005), suggesting that ETR measurements provide an estimate of carbon fixation rate. The $F_{m}$ values determined just before treatment exposures were used to determine the NPQ of the respective samples which were exposed to different treatments to allow reliable comparisons to be made among treatments ( $\mathrm{Li}$ et al. 2003).

The distance between the specimens and the optic fiber head of PAM was kept constant (13 $\mathrm{mm}$ ) for each sample so that accurate measurement of $F_{o}$ and $F_{m}$ could be achieved. PAM measurements after stress and recovery were done at the same position on the coral samples as before stress to avoid spatial heterogeneity in active chlorophyll signals of coral tissues (Ralph et al. 2002). All measurements were made at 25 ${ }^{\circ} \mathrm{C}$. All corals except CAP-treated samples were immersed under filtered $(0.45 \mu \mathrm{m})$ seawater (FSW) during measurement.

\section{Curve fitting of light curves and statistical analyses}

ETR curves were fitted with the following equation (Platt et al. 1980):

$P=P_{s}\left[1-\exp \left(-\alpha E_{d} / P_{s}\right)\right] \exp \left(-\beta E_{d} / P_{s}\right)$

$P_{s}$ represents the maximum potential ETR in the absence of photoinhibition. $\alpha$ is the initial slope of light curve before the onset of saturation and represents the efficiency of light utilization. $E_{d}$ is the downwelling irradiance $(400-700 \mathrm{~nm})$. $\beta$ is the parameter characterizing photoinhibition. In the absence of photoinhibition in the light curves, where $\beta=0$, the function becomes:

$P=P_{m}\left[1-\exp \left(-\alpha E_{d} / P_{m}\right)\right]$

$P_{m}$ is the maximum ETR $\left(E T R_{\max }\right)$ at light saturation and thus represents the photosynthetic capacity.

The ETR curves were compared among the initial, after stress and after recovery measurements at each temperature and/or light treatment by repeated measures analysis of variance (rm ANOVA). Since $F_{v} / F_{m}, E T R_{\max }$ and NPQ did not change significantly in corals that were kept at $25^{\circ} \mathrm{C}$ in darkness for $1 \mathrm{~h}$ and after $6 \mathrm{~h}$ recovery under dim light, it was used as control treatment. $F_{v} / F_{m}, E T R_{\max }$ and $\mathrm{NPQ}$ of the rest of the treatments were compared to the control. These comparisons were tested non-parametrically by Kruskal-Wallis test for analysis of variance by ranks. Relative values for $F_{v} / F_{m}, E T R_{\max }$ and $\mathrm{NPQ}$, that is, values normalized to the initial (before experimentation) ones, are independent of the topology of the coral fragments and thus were used for reliable comparison among treatments.

\section{RESULTS}

Maximum electron transport rate $\left(E_{T} T R_{\max }\right)$ and the maximum quantum yield of PSII $\left(F_{1} / F_{m}\right)$ after stress treatments and recovery

Since the $E T R_{\max }$ and $F_{v} / F_{m}$ represent the maximum electron transport rate and the maximum quantum yield of PSII, respectively, these two parameters were used in order to examine whether or not the primary site of thermal damage is the PSII in the photosynthetic apparatus of the zooxanthellae in Pachyseris rugosa exposed to light and heat stress (Fig. 1,2). Comparison of rapid light curves for the electron transport rate between initial and either dark (Fig. 1A) or illuminated (Fig. 1B) $25^{\circ} \mathrm{C}$ treated corals did not reveal any significant deviations in ETR curves ( $\mathrm{rm}$ ANOVA, $P>0.05$ ), but exposure to $33.5^{\circ} \mathrm{C}$ did cause a significant decline in $E T R_{\max }$ both in darkness and under illumination ( $\mathrm{rm}$ ANOVA, $P$ $<0.001$ ) (Fig. 1C, D). The $1 \mathrm{~h}$ light stress (1030 $\mu \mathrm{mol}$ quanta $\mathrm{m}^{-2} \mathrm{~s}^{-1}$ ) was sufficient to significantly affect the maximum quantum yield of PSII in $P$. rugosa under the control temperature conditions $\left(25^{\circ} \mathrm{C}\right.$, Kruskal-Wallis test, $P<0.05$, Fig. 2A). The combined effect of the light and temperature stresses $\left(33.5^{\circ} \mathrm{C}\right)$ resulted in more pronounced decline in relative $F_{v} / F_{m}$ (KruskalWallis test, $P<0.05$ ). In both cases, the disruption of photosynthesis was not restored to normal activity after the $6 \mathrm{~h}$ recovery under dim light. After exposure to $33.5^{\circ} \mathrm{C}$ in darkness, only the relative $E T R_{\max }$ suffered a pronounced but completely reversible decrease (Fig. 2). Although the relative $E T R_{\max }$ of $P$. rugosa exposed to $33.5^{\circ} \mathrm{C}$ decreased significantly to the same extent both in darkness and under illumination (KruskalWallis test, $P<0.05$ ), the recovery was incomplete after $6 \mathrm{~h}$ only in the light-treated samples.

\section{Non-photochemical quenching upon stress treatments and recovery}

The non-photochemical quenching (NPQ), a thermal dissipation process, was determined for the in hospite zooxanthellae before, after $1 \mathrm{~h}$ treatments and after $6 \mathrm{~h}$ recovery (Fig. 3). NPQ monitoring revealed reversible but significantly higher energy dissipation in PSII under high temperature and/or light levels used in this 


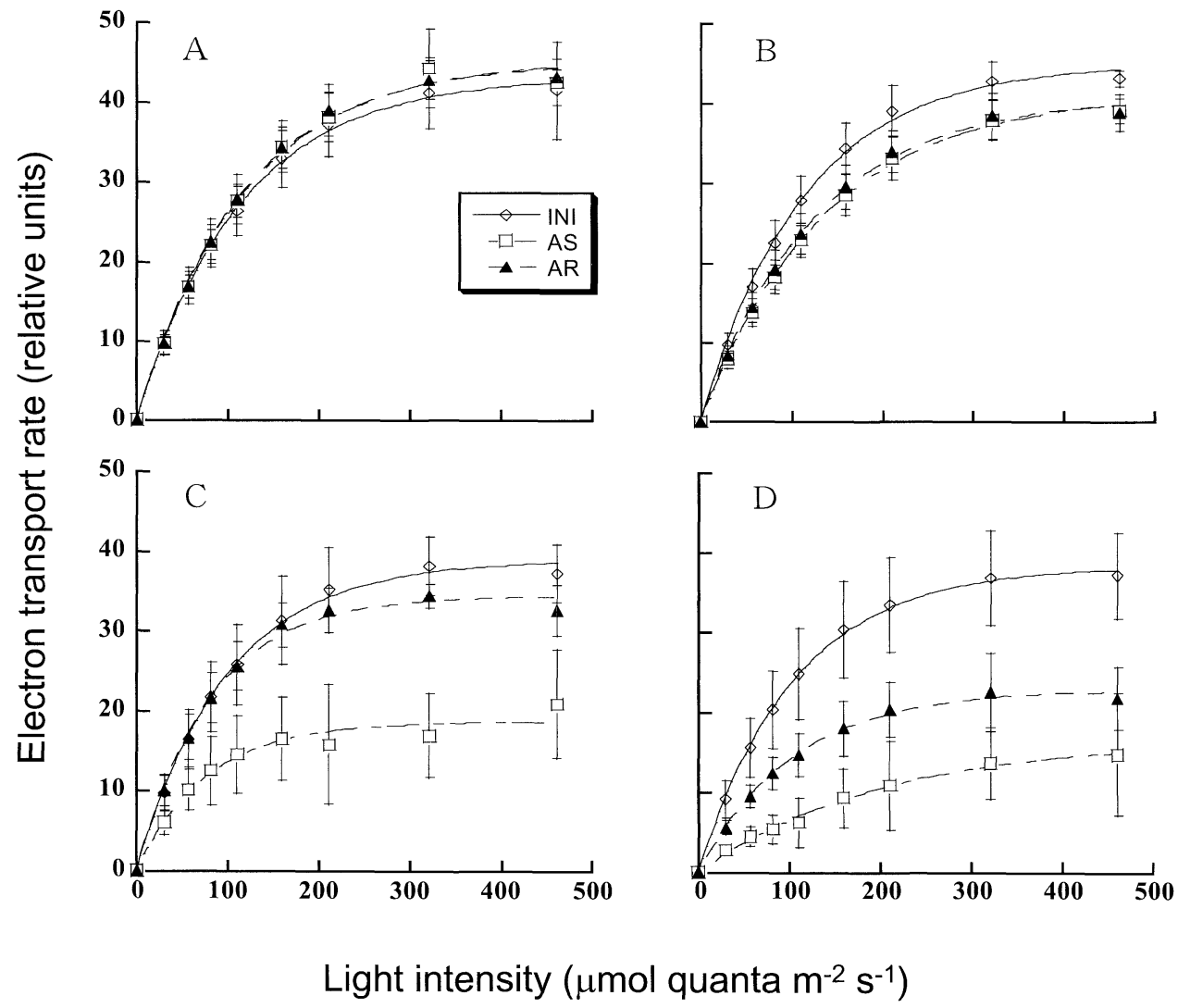

Fig. 1. Rapid light curves for the electron transport rate of in hospite zooxanthellae of Pachyseris rugosa initially $(\diamond)$, after $1 \mathrm{~h}$ treatment $(\square)$ at $25^{\circ} \mathrm{C}\left(\mathrm{A}\right.$, dark and $\mathrm{B}$, illuminated at $1030 \mu$ mol quanta $\left.\mathrm{m}^{-2} \mathrm{~s}^{-1}\right)$ and $33.5^{\circ} \mathrm{C}(\mathrm{C}$, dark and $\mathrm{D}$, illuminated at $1030 \mu \mathrm{mol}$ quanta $\left.\mathrm{m}^{-2} \mathrm{~s}^{-1}\right)$, and after $6 \mathrm{~h}$ recovery $(\boldsymbol{\Delta})$ in dim light. Number of replicates was 4 , except in graph $\mathrm{C}$, where $\mathrm{n}=3$. Solid, semi-broken and broken lines represent curve fitting for initial, after $1 \mathrm{~h}$ treatment and after $6 \mathrm{~h}$ recovery, respectively. Means + SD.



Fig. 2. Maximum quantum yield of PSII, $F_{v} / F_{m}$, (empty bars) and maximum electron transport rate, $E T R_{\max }$, (filled bars) relative to their respective initial values after $1 \mathrm{~h}$ treatment (A) and $6 \mathrm{~h}$ recovery (B) for in hospite zooxanthellae of the coral Pachyseris rugosa. Mean \pm SD. $\mathrm{N}=4$, except for $33.5^{\circ} \mathrm{C}$ treatment in darkness, where $\mathrm{n}=3$. Different letters indicate significant differences at $P<0.05$ (Kruskal-Wallis test) when the different treatments are compared to the control ones. Capital and small letters represent comparisons for $F_{v} / F_{m}$ and $E_{T R} R_{\max }$, respectively. $25+\mathrm{D}, 25^{\circ} \mathrm{C}$ in dark; $25+\mathrm{L}, 25^{\circ} \mathrm{C}$ under $1030 \mu \mathrm{mol}$ quanta $\mathrm{m}^{-2} \mathrm{~s}^{-1} ; 33.5+\mathrm{D}, 33.5^{\circ} \mathrm{C}$ in dark; $33.5+\mathrm{L}, 33.5^{\circ} \mathrm{C}$ under $1030 \mu \mathrm{mol}$ quanta $\mathrm{m}^{-2} \mathrm{~s}^{-1}$. 


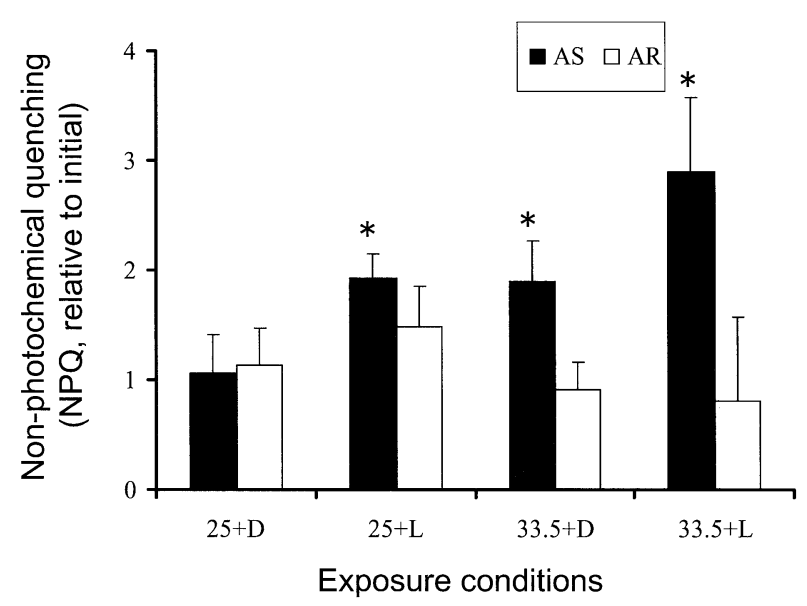

\begin{abstract}
Fig. 3. Non-photochemical quenching (NPQ) relative to their respective initial values after $1 \mathrm{~h}$ treatment (filled bars) and $6 \mathrm{~h}$ recovery (empty bars) for in hospite zooxanthellae of the coral Pachyseris rugosa. Mean $\pm \mathrm{SD} . \mathrm{N}=4$, except for $33.5^{\circ} \mathrm{C}$ treatment in darkness, where $\mathrm{n}=3$. Significant differences between the controls and treatments are indicated by asterisk (Kruskal-Wallis test, $\mathrm{P}<0.05$ ). $25+\mathrm{D}, 25^{\circ} \mathrm{C}$ in dark; $25+\mathrm{L}, 25^{\circ} \mathrm{C}$ under $1030 \mu \mathrm{mol}$ quanta $\mathrm{m}^{-2} \mathrm{~s}^{-1} ; 33.5+\mathrm{D}, 33.5^{\circ} \mathrm{C}$ in dark; $33.5+\mathrm{L}, 33.5^{\circ} \mathrm{C}$ under $1030 \mu \mathrm{mol}$ quanta $\mathrm{m}^{-2} \mathrm{~s}^{-1}$.
\end{abstract}

study. Both high temperature in darkness and control temperature under high light treated samples exhibited two-fold higher NPQ (KruskalWallis test, $P<0.05$ ), while the combined high temperature and light treated samples showed three-fold higher NPQ compared to the control treatment (Kruskal-Wallis test, $P<0.05)$. NPQ for the recovered samples treated under any conditions were not significantly different when compared to control ones (Kruskal-Wallis test, $P>0.05)$.

Relationship between maximum quantum yield of PSII or active PSII centers and maximum electron transport rate

In order to examine the extent to which the maximum quantum yield of PSII and the active PSII centers are in excess of the maximum electron transport rate in zooxanthellae of $P$. rugosa, the relationships between the maximum quantum yield of PSII $\left(F_{v} / F_{m}\right)$ or active PSII centers $\left(F_{v} / F_{o}\right)$ and maximum electron transport rate $\left(E T R_{\max }\right)$ were studied with or without CAP, which prevents the repair of PSII reaction center D1 protein (Fig. 4). In the absence of CAP, the $F_{v} / F_{m}$ decreased approximately linearly for the first $3 \mathrm{~h}$ to $60 \%$ of its initial value. Then it maintained the reduced level for the following $5 \mathrm{~h}$, while the $E T R_{\max }$ was not affected during the $8 \mathrm{~h}$ experimental period (Fig. 4A). In the presence of CAP, the $E T R_{\max }$ was not affected significantly for the first $15 \mathrm{~min}$, while $F_{v} / F_{m} \mathrm{de}^{-}$ creased to about $70 \%$. The $E T R_{\max }$ value started to decrease when $F_{v} / F_{m}$ value decreased beyond $60 \%$ of its initial value (Fig. 4B). These findings indicate that more than $40 \%$ inhibition of the maximum quantum yield of PSII (Fig. 4B, inset) or $70 \%$ inactivation of PSII centers (Fig. 5) in symbiotic dinoflagellates limited their capacity for transporting electrons, i.e. relative $E T R_{\max }$, and further inactivation resulted in a linear decrease of $E T R_{\max }$ in proportion to the maximum quantum yield of PSII or active PSII centers (Fig. 4B - inset, Fig. 5).

\section{DISCUSSION}

Coral bleaching due to elevated temperature has been subject of photo-physiological studies, which have led to a better understanding of the mechanism of this phenomenon. Most of the investigations including this study showed that PSII damage occurs under combined heat and light stress conditions (Jones et al. 1998; Warner et al. 1999; Bhagooli and Hidaka 2003, 2004). Our detailed investigation indicates that a component beyond PSII, possibly at the level of the dark reaction, might be the primary step of heatinduced damage in the algal photosynthesis and PSII damage is secondary. This is also consistent with Jones et al. (1998), who suggested that the first target of heat stress was the Calvin cycle, based on the use of induction curves which showed a decrease in fluorescence yield when non-photochemical quenching is enhanced at high 




Fig. 4. Relative maximum quantum yield of PSII $\left(F_{v} / F_{m}\right.$, empty squares) and relative maximum electron transport rate $\left(E T R_{\max }\right.$, empty circles) of in hospite zooxanthellae of the coral Pachyseris rugosa exposed to $250 \mu \mathrm{m}$ ol quanta $\mathrm{m}^{-2} \mathrm{~s}^{-1}$ light intensity at ambient temperature $\left(25^{\circ} \mathrm{C}\right)$ for various lengths of time, in absence (A) and presence (B) of chloramphenicol. Mean $\pm \mathrm{SD}$. $\mathrm{N}=4$. Inset depicts the relationship between the relative maximum quantum yield of PSII and relative maximum electron transport rate, using pooled data $(n=52)$ from curve $\mathrm{A}$ and $\mathrm{B}$. Curve was fitted with a third order polynomial $\left(\mathrm{r}^{2}=0.88\right)$.

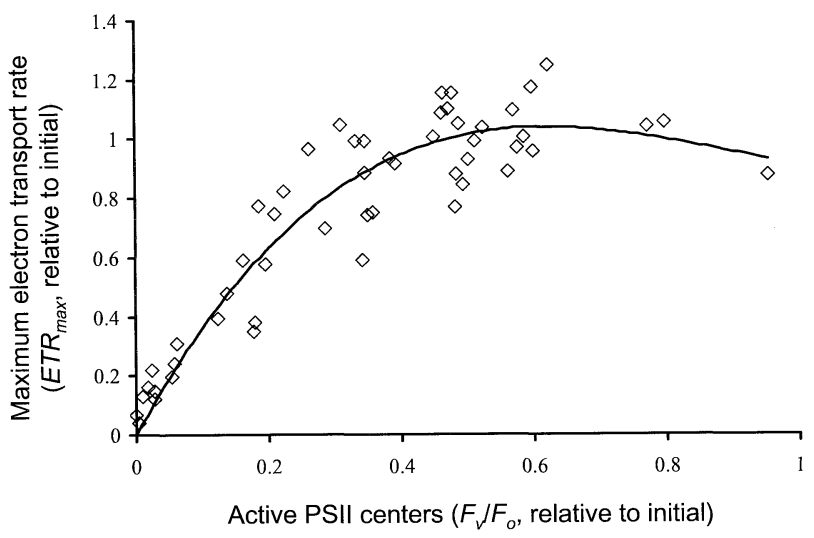

Fig. 5. Relationship between relative active PSII centers $\left(F_{v} / F_{0}\right)$ and relative maximum electron transport rate $\left(E T R_{\max }\right)$ from pooled data of CAP and non-CAP treated samples from Fig. 4. Data points represent relative values to the initial ones for respective samples $(n=52)$. Curve was fitted with a third order polynomial $\left(r^{2}=0.89\right)$

temperature.

\section{Effect of high light and elevated temperature on the maximum quantum yield of PSII and maximum electron transport rate}

The maximum quantum yield of PSII in the symbiotic dinoflagellates of Pachyseris rugosa was more sensitive to high light than to high temperature treatment, while the maximum electron transport rate was more sensitive to high temperature than to high light (Fig. 2). Photoinactivation of PSII and repair via de-novo protein synthesis occurs during normal photosynthesis, even under normal growth conditions (Sundby et al. 1993; Melis 1999). Under high light exposure the repair might not completely keep pace with photoinactivation/damage of the photosystem II. It thus results in net loss of functionality of PSII, but this does not necessarily affect the rest of the electron transport chain and the carbon fixation cycle. Such an inactivation or slow repair of the PSII, which is still within the range of maintaining the $E T R_{\max }$, might be an advantageous feature, since it protects the photosynthetic apparatus of the in hospite zooxanthellae by reducing the entry of excess electrons into 
the photosynthetic transport chain due to excess light energy. In other words, the slow rate of re-synthesis of D1 protein of PSII can act as a safety mechanism to protect excessive electron transport downstream PSII.

The high sensitivity of $E T R_{\max }$ to high temperature could possibly be result from the sensitivity of the Rubisco activase enzyme to high temperatures as has been shown in higher plants (Feller et al. 1998; Crafts-Brandner and Law 2000). Calvin cycle inhibition is characterized by a moderate drop in electron transport rate along with a strong enhancement of energy-dependent non-photochemical quenching (Jones et al. 1998). Our results indicate a significant decrease in $E T R_{\max }$ (Fig. 1C) concurrent with a significant increase in non-photochemical quenching (Fig. 3) under high temperature stress conditions. Thus, it is likely that the observed decrease in $E T R_{\max }$ in this study is due to the inhibition of Calvin cycle.

In hospite zooxanthellae exposed to high temperature showed no damage to the maximum quantum yield of PSII $\left(F_{v} / F_{m}\right)$, but a decreased ability to process absorbed light energy $\left(E T R_{\max }\right)$. Normal PSII activity accompanied by a reduced processing capability leads to over-reduction of the electron transport chain and production of active oxygen species. When high temperature and high light were used in combination, severe damage to PSII, reflected by decreased $F_{v} / F_{m}$, was observed. This can be explained by oxidative stress (Lesser 1997) generated as a consequence of blockage of electron flow downstream the PSII and the electrons reacting with oxygen molecules to form active oxygen species.

\section{Recovery of the maximum quantum yield of PSII and maximum electron transport rate from high temperature and/or high light treatments}

Differential restoration of the equally damaged $E T R_{\max }$ after high temperature treatment in darkness and after high temperature and high light treatments following the $6 \mathrm{~h}$ recovery period under dim light indicates possible damage to the recovery mechanism of the affected components contributing to $E T R_{\max }$ by light. Parallel recovery of the maximum quantum yield of PSII and the maximum electron transport rate were observed in corals exposed to combined high temperature and high light treatment (Fig. 2B). This implies that the repair of the PSII reaction center and the components of $E T R_{\max }$ occurred at a comparably equal rate. After the $6 \mathrm{~h}$ recovery period, the maximum quantum yield of PSII was restored to a mean of about $60 \%$, which normally should not limit the normal electron flow process (Fig. 4). The incomplete recovery of $E T R_{\max }$, along with the recovery of functional PSII to a level that can sustain the $E T R_{\max }$ after $6 \mathrm{~h}$ recovery, in the corals exposed to combined high temperature and high light will most likely make the photosynthetic machinery more vulnerable to normal irradiance, as more electrons will be flowing through the PSII than could be processed as $E T R_{\max }$. Thus the incomplete recovery of the damaged ETR components could be a more important determinant of further photodamage than PSII if corals are further exposed to either normal or high light.

Assessment of the relationship between the maximum quantum yield of PSII $\left(F_{1} / F_{m}\right)$ or active PSII centers $\left(F_{v} / F_{o}\right)$ and maximum photosynthetic rate $\left(E_{T R} R_{\text {max }}\right)$

Chloramphenicol is a chloroplast-encoded protein inhibitor, more specifically employed to inhibit PSII D1 protein synthesis in plants (Schnettger et al. 1994) and in zooxanthellae (Warner et al. 1999), and ensured the analysis of D1 protein degradation without re-synthesis. The maximum quantum yield of PSII decreased rapidly in the presence of CAP, suggesting that D1 protein re-synthesis was affected by this antibiotic (see Fig. 2A, B). The use of CAP in conjunction with light stresses for various lengths of exposure time allowed us to establish two phases in the relationships between the maximum quantum yield of PSII or the fraction of active PSII centers and the maximum electron transport rate measured by chlorophyll fluorescence technique (Fig. 4B - inset, Fig. 5). The initial linear phase (Fig. 5) might be interpreted as the maximum quantum yield of PSII or active PSII centers being a limiting factor in harnessing electrons from light and thus accounting for the linear decline of the $E T R_{\max }$ with decrease in $F_{v} / F_{m}$ or $F_{v} / F_{o}$. Furthermore, the percentage of the maximum quantum yield of PSII and active PSII centers reducing the $E T R_{\max }$ to half its initial value was estimated to be $30 \%$ (Fig. 4B inset) and $15 \%$ (Fig. 5), respectively. A reduction of the functional PSII to $19-36 \%$ has also been reported to reduce the maximum photosynthesis to half its normal value when using cultures of the marine diatom, Thalassiosira weissflogii, and the herbicide, 3-(3,4-dichlorophenyl)-1, 1-dimethylurea (DCMU), an inhibitor of PSII reaction centers functioning in conjunction with the oxygen evolution technique to determine maximum 
photosynthesis (Behrenfeld et al. 1998).

The plateau phase occurring in the $F_{v} / F_{m}$ range of $0.4-0.67(\sim 60 \%-100 \%$; Fig. $4 \mathrm{~B}-$ inset $)$, indicates that inactivation of PSII by up to $40 \%$ can still drive maximum ETR and hence maximum carbon fixation. Similar levels of partial inhibition of the maximum quantum yield of PSII that maintain $E T R_{\max }$ or maximum photosynthesis have been reported in higher plants as well as in zooxanthellae. A minimum of $52 \%$ of functional PSII in higher plants could maintain $100 \%$ of their maximum photosynthesis (Behrenfeld et al. 1998). Moreover, PSII of Capsicuum annuum leaves does not limit the maximum rate of photosynthesis until more than about $40 \%$ of PSII have been photoinactivated (Lee et al. 1999). Decrease in the maximum quantum yield of PSII of up to $60-70 \%$ still maintains the maximum electron transport rate in endosymbionts of corals in the field where they experience natural high sunlight levels during midday (HoeghGuldberg and Jones 1999).

\section{Damage and recovery of the maximum quantum yield of PSII and maximum electron transport rate}

The insensitivity of $E T R_{\max }$ to significant declines in the maximum quantum yield of PSII $\left(F_{v} / F_{m}\right)$ or active PSII centers $\left(F_{v} / F_{o}\right)$ in the relationship evaluation experiment clearly suggests that the overall photosynthetic electron flow can remain practically unchanged, although substantial PSII photodamage has occurred. This uncoupling between the maximum quantum yield of PSII or functional PSII centers and rates of electron flow suggests that photoinhibition of PSII is not directly influencing the rate-limiting step of photosynthesis. The elevated temperature exposure experiments showed that high temperature alone can inhibit the rate-limiting step of photosynthesis, as indicated by the reduction in $E T R_{\max }$. Furthermore, the restoration of PSII function up to a level that can maintain $E T R_{\max }$, accompanied by an incomplete recovery of $E T R_{\max }$, makes the photosynthetic machinery more vulnerable to even normal light levels and further heat damage. These findings indicate that damage in the process of $E T R_{\max }$ due to stress is more important than damage to PSII, though the incomplete recovery of some components of the photosynthetic machinery might add to that effect.

Takahashi et al. (2004) suggested that the repair system of D1 protein of PSII is the primary target of heat stress, as in their study the rate of recovery of $F_{v} / F_{m}$ after light-induced photoinhibition at 28 or $32^{\circ} \mathrm{C}$ was temperature-dependent. They also showed species-specific differences. If the repair system was inhibited by $\mathrm{CAP}$, the temperature effect disappeared and species-specific differences were reduced. However, $F_{v} / F_{m}$ of their samples recovered even in the presence of 600 $\mu \mathrm{M}$ CAP indicating that inhibition of $\mathrm{D} 1 \mathrm{pro}^{-}$ tein repair system was incomplete in their $\mathrm{ex}^{-}$ periments. Takahashi et al. (2004) also discussed that reactive oxygen species (ROS) might be involved in repair inhibition at high temperature. Since the production of ROS is enhanced through the inhibition of Calvin cycle, it is also possible that the primary target of heat stress is the Calvin cycle and the resulting production of ROS leads to increased damage of PSII and its repair inhibition as suggested by the present study.

Yakovleva and Hidaka (2004) compared the rate of recovery between PSII function and the dark reaction of zooxanthellae of two corals with different bleaching susceptibilities. They observed that the recovery of $E T R_{\max }$ after high temperature and high light stress treatment was slower than that of $F_{v} / F_{m}$ in a bleaching susceptible coral, Montipora digitata, and this delay of $E T R_{\max }$ recovery increased with increasing temperature during the recovery period. In a bleaching tolerant coral, Pavona divaricata, the recovery of $F_{v} /$ $F_{m}$ and $E T R_{\max }$ was almost complete within $24 \mathrm{~h}$ after stress treatment. They suggested that the difference in the rate of recovery between PSII function and the dark reaction (measured as $\left.E T R_{\max }\right)$ of zooxanthellae determines susceptibility of corals to bleaching.

The present study demonstrated that the electron transport beyond the PSII, possibly the dark reaction, might be the initial target of heat stress in zooxanthellae of the coral Pachyseris rugosa as evidenced by the combined measurements of $E T R_{\max }, \mathrm{NPQ}$ and $F_{v} / F_{m}$. Decreases in electron transport rate accompanied by increases in non-photochemical quenching under heatstress in our study indicate inhibition of the Calvin cycle enzymes as initial target of heat damage. This study further showed that, even when the PSII function and electron transport rate recovered to a similar extent, partial (around $60 \%$ ) recovery of PSII enabled the photosystem to generate enough electrons to drive the maximum electron transport rate, while these electrons cannot be fully consumed by an incompletely recovered electron transport system. Thus the recovery of the PSII up to a level that normally can maintain the maximum electron transport rate 
accompanied by an incomplete recovery of the latter might make the photosynthetic machinery of zooxanthellae more susceptible to oxidative stress under normal irradiance conditions.

\section{ACKNOWLEDGEMENTS}

The authors would like to thank I.M. Yakovleva, M.P. Lesser, J.-F. Flot, G. Winters, A.H. Baird and anonymous reviewers for their critical and insightful suggestions on the manuscript. The authors also wish to thank the staff of Sesoko Station, Tropical Biosphere Research Center, University of the Ryukyus, for allowing us to use the facilities. R.B. is thankful to the Ministry of Education, Culture, Sports, Science and Technology, Japan for a scholarship.

\section{REFERENCES}

Behrenfeld MJ, Prasil O, Kolber SZ, Babin M, Falkowski PG (1998) Compensatory changes in photosystem II electron turnover rates protect photosynthesis from photoinhibition. Photosynth Res 58: 259-268

Bhagooli R, Hidaka M (2002) Physiological responses of the coral Galaxea fascicularis and its algal symbiont to elevated temperatures. Galaxea, JCRS 4: 33-42

Bhagooli R, Hidaka M (2003) Comparison of stress susceptibility of in hospite and isolated zooxanthellae among five coral species. J Exp Mar Biol Ecol 291: 181-197

Bhagooli R, Hidaka M (2004) Photoinhibition, bleaching susceptibility and mortality in two scleractinian corals, Platygyra ryukyuensis and Stylophora pistillata, in response to thermal and light stresses. Comp Biochem Physiol Part A 137: 547-555

Brown BE, Ambarsari I, Warner ME, Fitt WK, Dunne RP, Gibb SW, Cummings DG (1999) Diurnal changes in photochemical efficiency and xanthophyll concentrations in shallow water reef corals: evidence for photoinhibition and photoprotection. Coral Reefs 18: 99-105

Crafts-Brandner SJ, Law RD (2000) Effect of heat stress on the inhibition and recovery of the ribulose-1,5-bisphosphate carboxylase/oxygenase activation state. Planta 212: 67-74

Crofts AR, Baroli I, Kramer D, Taoka S (1993) Kinetics of electron-transfer between Q (A) and $\mathrm{Q}(\mathrm{B})$ in wild-type and herbicide-resistant mutants of Chlamydomonas reinhardtii. $\mathrm{Z}$
Naturforsch 48c: 259-266

Feller U, Crafts-Brandner SJ, Salvucci ME (1998) Moderately high temperature inhibit ribulose-1,5-bisphosphate carboxylase/oxygenase (Rubisco) activase-mediated activation of Rubisco. Plant Physiol 116: 539-546

Fitt WK, Warner ME (1995) Bleaching patterns of four species of Caribbean reef corals. Biol Bull 187: 298-307

Genty B, Briantais JM, Baker NR (1989) The relationship between the quantum yield of photosynthetic electron transport and quenching of chlorophyll fluorescence. Biochem Biophys Acta 990: 87-92

Glynn PW (1993) Coral bleaching: ecological perspectives. Coral Reefs 12: 1-17

Hoegh-Guldberg O (1999) Climate change: coral bleaching and the future of the world's coral reefs. Mar Freshwater Res 50: 839-866

Hoegh-Guldberg O, Jones RJ (1999) Photoinhibition and photoprotection in symbiotic dinoflagellates from reef-building corals. Mar Ecol Prog Ser 183: $73-86$

Hoegh-Guldberg O, Smith GJ (1989) The effect of sudden changes in temperature, light and salinity on the population density and export of zooxanthellae from the reef corals Stylophora pistillata Esper and Seriatopora hystrix Dana. J Exp Mar Biol Ecol 129: 279-303

Iglesias-Prieto R, Matta JL, Robbins WA, Trench RK (1992) Photosynthesis response to elevated temperature in the symbiotic dinoflagellate Symbiodinium microadriaticum in culture, Proc Natl Acad Sci USA 89: 10302-10305

Jones RJ, Hoegh-Guldberg O, Larkum AWD, Schreiber U (1998) Temperature-induced bleaching of corals begins with impairment of the $\mathrm{CO}_{2}$ fixation mechanism in zooxanthellae. Plant Cell Environ 21: 1219-1230

Jones RJ, Ward S, Amri AY, Hoegh-Guldberg O (2000) Changes in quantum efficiency of photosystem II of symbiotic dinoflagellates of corals after heat stress, and of bleached corals sampled after the 1998 Great Barrier Reef mass bleaching event. Mar Freshwater Res 51: 63-71

Lee HY, Chow WS, Hong YN (1999) Photoinactivation of photosystem II in leaves of Capsicum annuum. Physiol Plant 105: 377-384

Lesser MP (1996) Exposure of symbiotic dinoflagellates to elevated temperatures and ultraviolet radiation causes oxidative stress and inhibits photosynthesis. Limnol Oceanogr 41: 271-283 
Lesser MP (1997) Oxidative stress causes coral bleaching during exposure to elevated temperatures. Coral Reefs 16: 187-192

Lesser MP, Gorbunov M (2001) Diurnal and bathymetric changes in chlorophyll fluorescence yields of reef corals measured with a fast repetition rate fluorometer. Mar Ecol Prog Ser 212: 69-77

Li XG, Meng QW, Jiang GQ, Zou Q (2003) The susceptibility of cucumber and sweet pepper to chilling under low irradiance is related to energy dissipation and water-water cycle. Photosyn 41: 259-265

Melis A (1999) Photosystem-II damage and repair cycle in chloroplasts: what modulates the rate of photodamage in vivo? Trends Plant Sci 4: 130-135

Platt T, Gallegos CL, Harrison WG (1980) Photoinhibition of photosynthesis in natural assemblages of marine phytoplankton. J Mar Res 38: 687-701

Ralph PJ, Gademann R, Larkum AWD, Kuhl M (2002) Spatial heterogeneity in active chlorophyll fluorescence and PSII activity of coral tissue. Mar Biol 141: 639-646

Schnettger B, Critchley C, Santore UJ, Graf M, Krause GH (1994) Relationship between photoinhibition of photosynthesis, D1 protein turnover and chloroplast structure: effects of protein synthesis inhibitors. Plant Cell Environ 17: 55-64

Sundby C, McCaffery S, Anderson JM (1993) Turnover of the photosystem II D1 protein in higher plants under photoinhibitory and nonphotoinhibitory irradiance. J Biol Chem 268: 25476-25482

Takahashi S, Nakamura T, Sakamizu M, van Woesik R, Yamasaki H (2004) Repair machinery of symbiotic photosynthesis as the primary target of heat stress for reef-building corals. Plant Cell Physiol 45: 251-255

Warner ME, Fitt WK, Schmidt GW (1996) The effects of elevated temperature on the photosynthetic efficiency of zooxanthellae in hospite from four different species of reef coral: a novel approach. Plant Cell Environ 19: 291299

Warner ME, Fitt WK, Schmidt GW (1999) Damage to photosystem II in symbiotic dinoflagellates: a determinant of coral bleaching. Proc Natl Acad Sci USA 96: 8007-8012

Wilkinson C (2000) Status of coral reefs of the world: 2000. Australian Institute of Marine Science, pp 363.

Wu T-Y, Dai C-F, Fan T-Y (2005) Effect of temperature on the oxygen and fluorescencebased estimates of photosynthetic parameters in the reef coral Stylophora pistillata. Proc 10th Int Coral Reef Symp (in press)

Yakovleva I, Hidaka M (2004) Differential recovery of PSII function and electron transport rate in symbiotic dinoflagellates as a possible determinant of bleaching susceptibility of corals. Mar Ecol Prog Ser 268: 43-53

(Received: 6 Sept. 2005/Accepted: 17 Jan. 2006)

造礁サンゴ褐虫藻の光化学系 II 最大量子収率と最大電 子伝達速度の高温による阻害と回復について

Ranjeet Bhagooli $^{* 1,2,3}$ - 日高道雄 ${ }^{1}$

${ }^{1}$ 琉球大学 理学部 海洋自然科学科

${ }^{2}$ Institute of Water and Environmental Resource Management, Department of Environmental Sciences, University of Technology, Sydney, Australia

The Biodiversity and Environment Institute, Reduit, Mauritius

サンゴの白化を引き起こす最初のステップは褐虫藻 の光化学系 II （PS II）の損傷であるかを調べるため に、シワリュウモンサンゴの褐虫藻において、PSII の活性を示す PS II 最大量子効率 $\left(F_{v} / F_{m}\right)$ またはアク ティブPS II 中心 $\left(F_{v} / F_{0}\right)$ とPS II の下流での電子の流 れの指標である最大電子伝達速度 $\left(E T R_{\text {max }}\right)$ の関係を 調べた。次に、高温 $\left(33.5^{\circ} \mathrm{C}\right)$ または強光 $(1030$ $\mu \mathrm{mol}$ quanta $\mathrm{m}^{-2} \mathrm{~s}^{-1}$ ) 1 時間処理後および 6 時間回 復後のこれらパラメータの変化を調べた。暗黒下で 1 時間高温処理すると、 $F_{v} / F_{m}$ は変化しなかったが、 $E T$ $R_{\text {max }}$ は有意な、しかし回復可能な低下を示した。1 時 間の強光処理は、 $F_{v} / F_{m}$ を低下させたが、 $E T R_{\text {max }}$ には影 響しなかった。強光十高温処理は、 $F_{v} / F_{m}$ をより顕著 に低下させ、ETR max $_{\text {ax }}$ 有意に低下させた。同時にPS II における熱消散を示す非光化学的消光 (NPQ) が 一時的に上昇した。 $F_{v} / F_{m} も E T R_{\max }$ も 6 時間では完全に 回復しなかった。PSII 反応中心のD1タンパクの合成 を阻害するクロラムフェニコールを用いた実験の結果、 $F_{v} / F_{m}$ の少なくとも $60 \%$ またはアクティブPS II 中心の 少なくとも $30 \%$ が機能していれば最大電子伝達速度 は維持された。褐虫藻光合成系の高温による損傷は、 最初にPS II 以降の要素、おそらく炭素固定回路、に 生じ、PS II の損傷は 2 次的なものであることが示唆 された。 